University of Nebraska - Lincoln

DigitalCommons@University of Nebraska - Lincoln

Faculty Papers and Publications in Animal

Science

Animal Science Department

2007

\title{
Carcass Traits and M. Longissimus Lumborum Palatability Attributes of Calf- and Yearling-Finished Steers
}

\author{
P. S. Brewer \\ University of Nebraska-Lincoln \\ J. M. James \\ University of Nebraska-Lincoln \\ Chris R. Calkins \\ University of Nebraska-Lincoln, ccalkins1@unl.edu \\ Richard J. Rasby \\ University of Nebraska-Lincoln, rrasby1@unl.edu \\ Terry J. Klopfenstein \\ University of Nebraska-Lincoln, tklopfenstein1@unl.edu \\ See next page for additional authors
}

Follow this and additional works at: https://digitalcommons.unl.edu/animalscifacpub

Part of the Animal Sciences Commons

Brewer, P. S.; James, J. M.; Calkins, Chris R.; Rasby, Richard J.; Klopfenstein, Terry J.; and Anderson, R. V., "Carcass Traits and M. Longissimus Lumborum Palatability Attributes of Calf- and Yearling-Finished Steers" (2007). Faculty Papers and Publications in Animal Science. 542.

https://digitalcommons.unl.edu/animalscifacpub/542

This Article is brought to you for free and open access by the Animal Science Department at DigitalCommons@University of Nebraska - Lincoln. It has been accepted for inclusion in Faculty Papers and Publications in Animal Science by an authorized administrator of DigitalCommons@University of Nebraska - Lincoln. 


\section{Authors}

P. S. Brewer, J. M. James, Chris R. Calkins, Richard J. Rasby, Terry J. Klopfenstein, and R. V. Anderson 


\title{
Carcass traits and M. longissimus lumborum palatability attributes of calf- and yearling-finished steers ${ }^{1}$
}

\author{
P. S. Brewer, J. M. James, C. R. Calkins, ${ }^{2}$ R. M. Rasby, T. J. Klopfenstein, \\ and R. V. Anderson
}

Department of Animal Science, University of Nebraska, Lincoln 68583-0908

\begin{abstract}
A 2-yr experiment was conducted to compare carcass characteristics and meat palatability attributes of steers ( $3 / 4$ British, $1 / 4$ Continental) finished postweaning as calves or yearlings. Calves and yearlings of the same contemporary group were designated to a finishing system at weaning. Calves $(n=73)$ were finished in the feedlot (191 d) on a high-concentrate diet. Yearlings $(n=84)$ grazed crop residues after weaning, followed by spring and summer pasture grazing, and concluded with a short finishing period (91 d) in the feedlot. All steers were fed to a constant, fat thickness endpoint of $1 \mathrm{~cm}$. The M. longissimus lumborum steaks from each production system were aged for 7, 14, or 21 $\mathrm{d}$ for Warner-Bratzler shear force determination and for 7 or $14 \mathrm{~d}$ for in-house sensory panel evaluation. Insoluble, percent soluble, and total collagen were determined. Yearlings produced heavier $(P<0.001)$ carcasses with larger $(P<0.001) \mathrm{LM}$ areas and lower $(P$ $<0.001)$ marbling scores and quality grades. Calves possessed greater amounts of total collagen $(P<0.001)$, with a significantly greater percentage of soluble collagen compared with yearlings (39.72 vs. $24.38 \%$ ). Calves
\end{abstract}

produced steaks with lower $(P<0.001)$ shear force values and greater $(P<0.001)$ sensory ratings for flavor. The USDA Choice steaks from the calves were more $(P$ $<0.001)$ tender and more $(P<0.050)$ palatable than Choice steaks from yearlings, and USDA Select steaks from calves were rated more tender $(P<0.001)$, juicy $(P=0.012)$, and desirable $(P<0.001)$ than Select steaks from yearlings. As expected, increasing aging time from 7 - to 14 - to 21 -d produced steaks with lower $(P<0.001)$ shear force values, regardless of the production system. Risk probabilities showed $1.24 \%$ of the steaks from calffinished steers and $21.22 \%$ of steaks from yearling-finished steers to be tough. Sensory rating probabilities showed the steaks from the calves were most likely to be desirable for tenderness, whereas steaks from the yearlings were most likely to be undesirable for tenderness, juiciness, flavor, and overall acceptability. Thus, calf-finished steers produce carcasses superior in quality and palatability compared with those from yearlingfinished steers. However, yearling-finished steers can produce tender beef with extended aging.

Key words: beef, production system, meat quality, collagen

(C2007 American Society of Animal Science. All rights reserved.

J. Anim. Sci. 2007. 85:1239-1246

doi:10.2527/jas.2006-026

\section{INTRODUCTION}

Most conventional, intensive finishing systems in the United States use large amounts of grain in high-concentrate diets fed to weanling calves for extended periods of time. In contrast, yearling systems are more extensive, growing calves for a longer period of time on forage before feeding a high-concentrate diet for a short period before slaughter. This reduction in days on a

\footnotetext{
${ }^{1}$ A contribution of the University of Nebraska Agricultural Research Division, Lincoln 68583. Journal Series No. 15094.

${ }^{2}$ Corresponding author: ccalkins1@unl.edu

Received January 12, 2006.

Accepted December 20, 2006.
}

high-concentrate diet may reduce feeding costs, but decreased days on feed has been associated with lower quality grades and less tender beef (Miller et al., 1987; May et al., 1992). Regardless of the management practice used to increase profitability, cattle must be acceptable to the feedlots and yield a final product desirable to consumers.

The literature provides varied results when comparing carcass and palatability traits from finished calves and yearlings. Calves have been reported to produce carcasses with increased fat thickness and numerically greater yield grades and quality grades (Lunt and Orme, 1987), as well as more tender meat (Dikeman et al., 1985b; Johnson et al., 1990). However, others have shown minimal effects of the finishing system on carcass quality grade or meat palatability (Dikeman et al., 1985a; Huffman et al., 1990). Harris et al. (1997) 
compared cloned steers finished as calves or yearlings and reported that the calves had heavier carcasses, numerically greater yield grades, and greater quality grades when fed to an age-constant endpoint, whereas calves and yearlings fed to a constant weight yielded carcasses similar in weight and fat thickness, with no differences in quality grade. Neither endpoint in the latter study affected meat palatability between the calves and the yearlings.

Contradictory data could occur because of variable slaughter endpoints of age or weight. Genetic variation in the sample population may also result in inconsistent findings. Others have used a relatively small population ( $\mathrm{n}=20$, Lunt and Orme, 1987; $\mathrm{n}<10$, Harris et al., 1997).

Therefore, the objective of our study was to compare carcass characteristics and meat palatability of steers from a contemporary group, finished in a calf or yearling system, and fed to a constant fat thickness end point over a 2-yr span.

\section{MATERIALS AND METHODS}

Live animal procedures used in this study were approved by the university Institutional Animal Care and Use Committee. Steers used in this study were of a contemporary group, with similar genetics and preweaning management. Variation in the production systems did not exist until after weaning.

\section{Production Systems}

This 2-yr study was described by Anderson et al. (2005), who examined differences in production outcomes. This report evaluated the carcass traits and meat palatability attributes of calf-finished $(\mathbf{C F})$ and yearling-finished (YF) steers for the 2 yr. Steers $(3 / 4$ British, 1/4 Continental) were randomly assigned at weaning to be finished as calves or yearlings. Thirtyfive and 41 calves and 42 and 41 yearlings were used in yr 1 and 2 , respectively.

Each year at weaning, the steers to be finished as calves were transported to the feedlot, blocked by BW, randomly assigned to 1 of 2 pens, and implanted with Synovex-S (Fort Dodge Animal Health, Overland Park, $\mathrm{KS})$. A series of 5 step-up rations were fed after a 28$\mathrm{d}$ receiving period, beginning with a $50 \%$ concentrate diet and progressing to a $90 \%$ concentrate finishing diet (TDN 84\%, CP 12\%; DM basis) that was fed until slaughter. Reimplantation (Revalor-S, Intervet Inc., Millsboro, DE) occurred after $90 \mathrm{~d}$ on feed. All steers were fed to a visually estimated average endpoint of 1 $\mathrm{cm}$ of fat thickness at the 12th rib. To achieve this, yr $1 \mathrm{CF}$ steers were on feed for $203 \mathrm{~d}$, and yr $2 \mathrm{CF}$ steers were fed for $180 \mathrm{~d}$. Calf-finished steers were approximately 13- to 14-mo-old at the time of slaughter.

Steers to be finished as yearlings were fed ammoniated wheat straw ad libitum and supplemented with mineral and $2.27 \mathrm{~kg} \cdot \mathrm{head}^{-1} \cdot \mathrm{d}^{-1}$ (DM basis) of wet corn gluten feed (90\% TDN, 24\% CP, DM basis) for $60 \mathrm{~d}$, until cornstalks became available for grazing. Steers then grazed cornstalks for $78 \mathrm{~d}$ in yr 1 and $91 \mathrm{~d}$ in yr 2 . While on the cornstalks, the steers were supplemented with mineral and $2.27 \mathrm{~kg} \cdot \mathrm{head}^{-1} \cdot \mathrm{d}^{-1}$ (DM basis) of corn gluten feed. Hay was supplemented during heavy snow cover. After grazing the cornstalks, the steers were maintained on ammoniated wheat straw ad libitum, mineral, and corn gluten feed for the remainder of the wintering period (64 $\mathrm{d}$ in yr 1 and $50 \mathrm{~d}$ in yr 2) until pasture was available for spring and summer grazing. Steers were then grazed on spring and summer pastures for $96 \mathrm{~d}$ in yr 1 and $103 \mathrm{~d}$ in yr 2. Steers were implanted (Revalor-G, Intervet Inc., Millsboro, DE) after a 25-d spring grazing period. Spring grazing pastures consisted of smooth bromegrass. Summer grazing pastures consisted of big bluestem, Indiangrass, and switchgrass.

After the summer grazing period, the steers entered the feedlot, were reimplanted (Revalor-S), blocked by BW, and assigned randomly to 1 of 2 pens. The steers were fed similarly to the calves for the receiving and finishing periods. This final finishing period consisted of $93 \mathrm{~d}$ in yr 1 and $90 \mathrm{~d}$ in yr 2. Yearling-finished steers were approximately 19 - to 20 -mo-old at the time of slaughter.

\section{Slaughter}

Steers were slaughtered in a commercial slaughter facility (Excel Corp., Schuyler, NE). Shortly after exsanguination, the carcasses were electrically stimulated with 8 to 10 low-voltage $(40 \mathrm{~V})$ pulses. The HCW were obtained from all steers at the time of slaughter. In yr 1, the carcasses were chilled for an extended 48$\mathrm{h}$ weekend period. The carcasses in yr 2 were chilled for approximately $42 \mathrm{~h}$. After the chill period, the carcasses were ribbed to expose the 12 th rib interface and allowed to bloom for approximately $20 \mathrm{~min}$. A marbling score was then assigned by a USDA grader. Fat thickness, adjusted fat thickness, LM area, and KPH were measured and evaluated at this time by experienced University of Nebraska personnel. Carcass measurements were used to calculate yield grades. A boneless beef strip loin, IMPS \#180 (NAMP, 1997), was collected from the left side of each carcass. The LM were identified, vacuum-packaged, boxed, and transported to the University of Nebraska meat laboratory, Lincoln. Two LM from CF steers were lost during the fabrication process, so additional data analysis continued on 34 and $40 \mathrm{LM}$ for CF steers in yr 1 and 2, respectively. The LM were received and placed in a cooler at $1^{\circ} \mathrm{C}$, where they remained until further analysis.

At $7 \mathrm{~d}$ postmortem, the LM were cut into $2.5-\mathrm{cm}$ thick steaks for proximate analysis, Warner-Bratzler shear force (WBS), and in-house sensory panel evaluation. The steaks were numbered from the cranial end and assigned to each analysis. Steak 1 was designated for proximate analysis, trimmed of external fat and 
epimysium, and frozen immediately. Steaks 2 through 4 were used to determine WBS at 7, 14, and $21 \mathrm{~d}$ of age. Steaks 5 through 8 were aged for $7 \mathrm{~d}$, and steaks 9 through 12 were aged for $14 \mathrm{~d}$ and used for sensory panel evaluations. The steaks were packaged in freezer paper, and after the designated 7-, 14-, or 21-d aging time, were frozen at $-22^{\circ} \mathrm{C}$.

\section{Proximate Analysis}

Trimmed steaks were powdered in liquid nitrogen using a Waring blender (Waring Products Division, New Hartford, CT). Duplicate samples were analyzed for moisture and ash using a Leco Thermogravimetric Analyzer-601 (Model 604-100-400, Leco Corp., St. Joseph, MI) with a TGA-601 Windows (version 1.2, Leco Corp.) option. For lipid content, duplicate samples were analyzed using the Soxhlet method; the samples were distilled in anhydrous ether (Fisher Scientific, Denver, CO) for $72 \mathrm{~h}$ (AOAC, 1990).

\section{Warner-Bratzler Shear Force}

Frozen steaks were thawed at $4^{\circ} \mathrm{C}$ for $24 \mathrm{~h}$ and trimmed of external fat and muscles other than the LM. The steaks were cooked on Farberware Open-Hearth broilers (Model 455N, Walter Kidde and Co., Bronx, $\mathrm{NY}$ ) to an internal temperature of $40^{\circ} \mathrm{C}$, turned, and cooked to a final internal temperature of $70^{\circ} \mathrm{C}$ (AMSA, 1995). The internal temperature was monitored using an Omega 450ATT thermometer with a type T thermocouple (Omega Engineering Inc., Stamford, CT). The steaks were cooled for approximately $4 \mathrm{~h}$ at $4^{\circ} \mathrm{C}$ before removal of 8 to 10 cores $(1.27-\mathrm{cm}$ diam.) parallel to the longitudinal axis of the muscle fibers. Shearing was done on an Instron Universal Testing Machine (Model 55R1123, Canton, MA) with a Warner-Bratzler shear attachment. The Instron was set up with a crosshead speed of $250 \mathrm{~mm} / \mathrm{min}$, and a load cell of $500 \mathrm{~kg}$. An average of the peak shear force $(\mathrm{kg})$ of at least 6 sheared cores was calculated for each steak.

\section{Collagen Determination}

Powdered LM samples from the CF and YF steers were analyzed for soluble, insoluble, and total collagen according to the methods of Bergman and Loxley (1963) and Hill (1966), as modified by Cross et al. (1973). Briefly, $12 \mathrm{~mL}$ of heated, one-quarter-strength Ringer's solution was added to $3 \pm 0.02 \mathrm{~g}$ of powdered sample and heated for $80 \mathrm{~min}$ in a $70^{\circ} \mathrm{C}$ water bath, stirring every $5 \mathrm{~min}$. The samples were centrifuged for $10 \mathrm{~min}$ at 5,200 $\times g$ (Sorvall RC-5B, SA-600 rotor, DuPont Instruments, Newtown, CT). The supernatant was decanted into flasks for determination of the soluble portion. Eight milliliters of one-quarter-strength Ringer's were added to the samples, centrifuged, and the soluble portion was again placed into the flask. Twenty-five milliliters of hydrochloric acid was added to the soluble and insoluble portions as well as samples for total collagen and autoclaved for $18 \mathrm{~h}$ at $121^{\circ} \mathrm{C}$ at 124 to $138 \mathrm{kPa}$.

The sample hydrolysate was mixed with $1 \mathrm{~g}$ of charcoal (Sigma-Aldrich Inc., St. Louis, MO), filtered (Whatman \#4, Whatman Int. Ltd., Springfield Mill, Maidstone, Kent, UK), and diluted with double-distilled water to 1,000 or $500 \mathrm{~mL}$ for insoluble and soluble assays, respectively. One milliliter of sample, $2 \mathrm{~mL}$ of isopropanol (VWR International, West Chester, PA), $1 \mathrm{~mL}$ of oxidant solution, and $4 \mathrm{~mL}$ of Ehrlich's reagent (5.33:1 $\mathrm{vol} / \mathrm{vol}$ of isopropanol and dimethylaminobenzaldehyde, the latter from Sigma-Aldrich Inc.) were added to the test tubes, with vortexing between each solution. The samples were placed in a $60^{\circ} \mathrm{C}$ water bath for $25 \mathrm{~min}$ and then read at $558 \mathrm{~nm}$ with a spectrophotometer (Cary 100 Bio UV-VIS Spectrophotometer, Varian Instruments, Sugar Land, TX) after obtaining a hydroxyproline (trans4-hydroxy-L-proline, H-5534, Sigma, St. Louis, MO) standard curve. Soluble collagen was calculated with a constant of 7.52, and insoluble collagen was calculated with a constant of 7.25 (Goll et al., 1963).

\section{Sensory Evaluation}

Steaks for sensory evaluation were cooked by the same procedure as described for WBS determinations, and cut into $1 \times 2 \times 1$-cm pieces for evaluation. Eight 3 -digit, randomly numbered samples were served to the panelists on 2 plates consisting of 4 samples (1 steak from a CF steer aged for 7 or $14 \mathrm{~d}$, and 1 steak from a YF steer aged for 7 or $14 \mathrm{~d}$ ) each. This ensured that the steaks aged 7 or $14 \mathrm{~d}$ from the same animal were served within the same panel. During the panel session, the samples were held in double broilers to maintain their temperature. After no more than $20 \mathrm{~min}$, any remaining samples were discarded, and a matching steak from that treatment was used for the panel.

The samples were served to an in-house sensory panel $(n \geq 30)$ in individual booths under red lighting to mask any differences in meat color. The panelists were recruited from faculty, staff, students, and area residents who ate red meat regularly, were 19+ yr of age, and were not involved with the project (Brandt, 1998; Resurreccion, 1998). Each treatment received at least 2,220 panelist impressions ( 74 animals $\times 30$ panelists for $\mathrm{CF}$, and 83 animals $\times 30$ panelists for $\mathrm{YF})$. An 8 -point hedonic scale ( $8=$ extremely desirable; $7=$ very desirable; 6 = moderately desirable; 5 = slightly desirable; 4 = slightly undesirable; $3=$ moderately undesirable; 2 = very undesirable; 1 = extremely undesirable) was used to evaluate tenderness, juiciness, flavor, and overall acceptability.

\section{Statistical Analysis}

Carcass traits, chemical characteristics, WBS, and sensory panel data were analyzed as a completely randomized design using the GLM procedure (SAS Inst. Inc., Cary, NC). Both years were pooled, and each steer 
Table 1. Comparison of carcass characteristics from calf- and yearling-finished steers

\begin{tabular}{|c|c|c|c|c|c|}
\hline \multirow[b]{2}{*}{ Item } & \multicolumn{2}{|c|}{ Calves } & \multicolumn{2}{|c|}{ Yearlings } & \multirow[b]{2}{*}{$P$-value } \\
\hline & Mean & SE & Mean & SE & \\
\hline $\mathrm{HCW}, \mathrm{kg}$ & 315.4 & 3.37 & 375.9 & 3.18 & $<0.001$ \\
\hline Fat thickness, cm & 1.39 & 0.045 & 1.30 & 0.042 & 0.188 \\
\hline Adjusted fat thickness, $\mathrm{cm}$ & 1.50 & 0.039 & 1.42 & 0.037 & 0.148 \\
\hline $\mathrm{LM}$ area, $\mathrm{cm}^{2}$ & 72.76 & 0.67 & 81.06 & 0.63 & $<0.001$ \\
\hline $\mathrm{KPH}, \%$ & 2.33 & 0.053 & 2.07 & 0.05 & $<0.001$ \\
\hline Yield grade & 3.49 & 0.054 & 3.46 & 0.05 & 0.642 \\
\hline Marbling score $^{1}$ & 454.1 & 8.80 & 346.1 & 8.28 & $<0.001$ \\
\hline
\end{tabular}

${ }^{1}$ Marbling score: modest $=500-599 ;$ small $=400-499 ;$ and slight $=300-399$.

was an experimental unit for carcass traits and chemical characteristics. Steaks at each aging time were the experimental units for shear force and sensory evaluations. Due to the difference in quality grades between the 2 treatments, the data were reanalyzed as a factorial arrangement with grade added to the model as a fixed effect. Separation of the mean was performed with Fisher's protected least significant difference test. A predetermined alpha value of 0.05 was used in this study.

The probabilities of the steaks being categorized into 1 of 3 tenderness groups (tender, intermediate, tough) were calculated using WBS value means and SD of steaks from each management system at each aging time. The 3 tenderness groups were categorized according to Miller et al. (2001), in which tender was a WBS force of $<3.0 \mathrm{~kg}$, intermediate was 3.0 to $4.6 \mathrm{~kg}$, and tough was $>4.6 \mathrm{~kg}$. Probabilities of the steaks being categorized into 1 of 3 desirability groups (desirable, slightly desirable, undesirable) were determined using sensory rating means and SD of each palatability trait for the steaks from each management system at each aging time. Limits were set for rating scores $>5.5$ on an 8-point scale as desirable, between 4.5 and 5.5 as slightly desirable, and $<4.5$ as undesirable. Frequency distribution data were generated to reveal the distribution of the steers within each group, and a $\chi^{2}$ statistic was determined.

\section{RESULTS AND DISCUSSION}

\section{Carcass Characteristics}

Carcass characteristics for $\mathrm{CF}$ and $\mathrm{YF}$ steers are summarized in Table 1. Yearling-finished steers yielded heavier $(P<0.001)$ carcasses with larger $(P<0.001)$ LM and less $(P<0.001) \mathrm{KPH}$. The CF steers had much greater $(P<0.001)$ marbling scores, USDA quality grades, and percentage of carcasses grading USDA Choice or greater $(\mathrm{CF}$ USDA Choice or greater = $66.22 \%, \mathrm{n}=49$ out of 74 ; YF USDA Choice $=15.67 \%$, $\mathrm{n}=13$ out of 83). All carcasses from CF or YF steers were A maturity. Calves fed for $217 \mathrm{~d}$ have previously been reported by Harris et al. (1997) to have greater marbling scores than yearlings fed for $93 \mathrm{~d}$, although calves were also reported to have heavier carcasses and greater numerical yield grades. However, when these researchers fed to a constant weight endpoint, calves fed $224 \mathrm{~d}$ had similar carcass weights and yield grades to yearlings fed $182 \mathrm{~d}$.

Mean marbling scores were greater $(P<0.001)$ for choice carcasses from CF than from YF steers (502 vs. 445). Select grade carcasses had similar marbling scores (338 vs. 332 for $\mathrm{CF}$ and YF, respectively). The percentage fat in the LM reflected these same differences (Table 2).

Sindt et al. (1991) summarized a comparison of calves and yearlings over $5 \mathrm{yr}$ and concluded that calves fed

Table 2. Chemical analysis of the LM of calf- and yearling-finished steers grading USDA Choice and Select ${ }^{1}$

\begin{tabular}{|c|c|c|c|c|c|c|}
\hline \multirow[b]{2}{*}{ Grade } & \multirow[b]{2}{*}{ Item } & \multicolumn{2}{|c|}{ Calves } & \multicolumn{2}{|c|}{ Yearlings } & \multirow[b]{2}{*}{$P$-value ${ }^{2}$} \\
\hline & & Mean & SE & Mean & SE & \\
\hline \multicolumn{7}{|l|}{ Choice } \\
\hline & Moisture & $68.08^{a}$ & 0.321 & $71.27^{\mathrm{b}}$ & 0.617 & $<0.001$ \\
\hline & Fat & $10.12^{\mathrm{a}}$ & 0.403 & $7.28^{\mathrm{b}}$ & 0.775 & 0.002 \\
\hline \multicolumn{7}{|l|}{ Select } \\
\hline & Moisture & $71.93^{\mathrm{b}, \mathrm{c}}$ & 0.445 & $72.79^{c}$ & 0.278 & 0.103 \\
\hline & Fat & $5.28^{\mathrm{c}}$ & 0.559 & $5.24^{\mathrm{c}}$ & 0.349 & 0.950 \\
\hline
\end{tabular}

${ }^{\mathrm{a}-\mathrm{c}} \mathrm{F}$ or each item (moisture or fat), means without a common superscript differ $(P<0.05)$.

${ }^{1}$ Treatment $\times$ grade interaction for fat, $P=0.012$; and treatment $\times$ grade interaction for moisture, $P=$ 0.009 .

${ }^{2}$ Simple effect for each row. 
Table 3. Mean Warner-Bratzler Shear (WBS) force and sensory ratings of the LM of calfand yearling-finished steers grading USDA Choice and Select ${ }^{1}$

\begin{tabular}{|c|c|c|c|c|c|c|}
\hline \multirow[b]{2}{*}{ Item $^{2}$} & \multirow[b]{2}{*}{ Grade } & \multicolumn{2}{|c|}{ Calves } & \multicolumn{2}{|c|}{ Yearlings } & \multirow[b]{2}{*}{$P$-value ${ }^{3}$} \\
\hline & & Mean & $\mathrm{SE}$ & Mean & $\mathrm{SE}$ & \\
\hline WBS & & 3.05 & 0.051 & 3.74 & 0.063 & $<0.001$ \\
\hline Flavor & & 4.97 & 0.023 & 4.67 & 0.029 & $<0.001$ \\
\hline Juiciness & Choice & $5.07^{\mathrm{a}}$ & 0.026 & $4.93^{\mathrm{b}}$ & 0.051 & 0.012 \\
\hline Tenderness & Choice & $5.62^{\mathrm{d}}$ & 0.028 & $4.77^{\mathrm{f}}$ & 0.055 & $<0.001$ \\
\hline Overall desirability & Choice & $5.11^{\mathrm{d}}$ & 0.026 & $4.65^{\mathrm{f}}$ & 0.051 & $<0.001$ \\
\hline Juiciness & Select & $4.87^{\mathrm{b}}$ & 0.036 & $4.57^{\mathrm{c}}$ & 0.022 & $<0.001$ \\
\hline Tenderness & Select & $5.43^{\mathrm{e}}$ & 0.039 & $4.41^{\mathrm{g}}$ & 0.024 & $<0.001$ \\
\hline Overall desirability & Select & $4.99^{\mathrm{e}}$ & 0.036 & $4.32^{\mathrm{g}}$ & 0.022 & $<0.001$ \\
\hline
\end{tabular}

twice as long as yearlings in the feedlot produced a greater percentage of carcasses grading USDA Choice or greater. The USDA Choice steaks from $\mathrm{CF}$ steers also had greater $(P<0.001)$ ether extractable lipid (Table 2$)$ compared with USDA Choice YF steaks, and numerically, USDA Choice and Select steaks from CF had less moisture. These data are consistent with Savell et al. (1986), who noted steaks with greater marbling scores had more extractable lipid and less moisture.

\section{Palatability Traits}

Most CF carcasses graded Choice, and most YF carcasses graded Select. To remove the effect of marbling differences between treatments, data were analyzed within quality grade. Most (95.5\%) of the carcasses graded USDA Choice or Select; thus steaks within these grades were used to compare $\mathrm{CF}$ and $\mathrm{YF}$ steers.

Steaks from $\mathrm{CF}$ carcasses had lower $(P<0.001) \mathrm{WBS}$ values (Table 3) than steaks from YF cattle. In this study, steaks from $\mathrm{CF}$ steers were rated significantly greater for flavor $(P<0.001)$ than YF steaks. Additionally, steaks from Choice $\mathrm{CF}$ steers were rated greater $(P<0.02)$ for juiciness, whereas steaks from Choice YF and Select $C F$ were similar $(P=0.419)$. Choice and Select steaks from CF steers were rated more tender and overall more desirable $(P<0.001)$ than the steaks from YF steers. Calves have previously been shown to produce more tender meat (Dikeman et al., 1985b;
Klopfenstein et al., 1995), although other palatability traits have been shown to be similar between calves and yearlings (Lunt and Orme, 1987; Johnson et al., 1990).

Schoonmaker et al. (2001) found early-weaned steers to be more tender than normally weaned steers and suggested this may be the result of a greater number of days on high-concentrate feed, a younger slaughter age, or a combination of the two. The same may be true in this study.

It is unlikely the tenderness differences are due to the implant differences in the $\mathrm{CF}$ vs. YF systems reported here. Schoonmaker et al. (2001) found no effects on WBS value (or sensory panel tenderness and juiciness ratings) comparing steers implanted with a total of $240 \mathrm{mg}$ of trenbolone acetate (TBA; Synovex-C, no TBA, followed twice with Revalor-S, $120 \mathrm{mg}$ of TBA) with those implanted with 2 doses of Synovex-S (no TBA). Similarly, Gerken et al. (1995) did not find any implant effects on WBS value or sensory panel tenderness when comparing cattle implanted with a single dose of Revalor-S (140 mg of TBA) vs. Synovex-S (no TBA). Foutz et al. (1997) compared shear force and percentage of tough steaks coming from cattle receiving a $120 \mathrm{mg}$ of TBA implant vs. those receiving 2 separate doses of a $120 \mathrm{mg}$ of TBA implant and reported no implant effects. Reiling and Johnson (2003) found no difference in shear force when cattle were implanted with $120 \mathrm{mg}$ of TBA vs. those implanted with 2 separate doses of an implant containing $120 \mathrm{mg}$ of TBA each.

Table 4. Collagen analysis of the LM from calf- and yearling-finished steers

\begin{tabular}{lrrrrrr}
\hline \hline & \multicolumn{2}{c}{ Calves } & & \multicolumn{2}{c}{ Yearlings } & \\
\cline { 2 - 3 } Item & Mean & $\mathrm{SE}$ & & Mean & $\mathrm{SE}$ & \\
\hline Insoluble collagen, mg/g & 8.11 & 0.391 & 6.19 & 0.357 & $<0.001$ \\
Soluble collagen, mg/g & 6.23 & 0.408 & & 2.21 & 0.372 & $<0.001$ \\
Total collagen, mg/g & 14.52 & 0.742 & 8.46 & 0.678 & $<0.001$ \\
Soluble collagen, \% & 39.72 & 2.528 & & 24.38 & 2.308 & $<0.001$ \\
\hline
\end{tabular}


Table 5. The effect of aging time on meat quality attributes of the LM from calf- and yearling-finished steers

\begin{tabular}{lccccccc}
\hline \hline Item $^{1}$ & $7 \mathrm{~d}$ & $\mathrm{SE}$ & $14 \mathrm{~d}$ & $\mathrm{SE}$ & $21 \mathrm{~d}$ & $\mathrm{SE}$ & $P$-value $^{2}$ \\
\hline WBS & $3.69^{\mathrm{a}}$ & 0.070 & $3.41^{\mathrm{b}}$ & 0.070 & $3.09^{\mathrm{c}}$ & 0.070 & $<0.001$ \\
Sensory juiciness & $4.98^{\mathrm{a}}$ & 0.025 & $4.79^{\mathrm{b}}$ & 0.025 & - & - & $<0.001$ \\
Sensory tenderness_Choice & $5.20^{\mathrm{a}}$ & 0.044 & $5.19^{\mathrm{a}}$ & 0.044 & - & - & 0.014 \\
Sensory tenderness-Select & $4.82^{\mathrm{c}}$ & 0.033 & $5.02^{\mathrm{b}}$ & 0.033 & - & - & \\
\hline
\end{tabular}

${ }^{\mathrm{a}-\mathrm{c}}$ Means within a row (WBS, sensory juiciness) or an item (sensory tenderness) without a common superscript letter differ $(P<0.05)$.

${ }^{1}$ WBS = Warner-Bratzler shear force, in kilograms .

${ }^{2} P$-value for the main effect or the interaction.

Steaks from the CF steers had a greater percentage of soluble collagen than steaks from YF steers (Table 4). This likely explains why steaks from the CF steers were more tender than steaks from YF steers in this study. Hill (1966) demonstrated that collagen solubility decreases in muscle as physiological age increases. Aberle et al. (1981) hypothesized that beef cattle fed highconcentrate diets would have greater protein turnover and thus greater collagen solubility that would allow for less cross-linkages and more tender beef. Cross et al. (1973) showed that tenderness ratings were more affected by greater degrees of soluble collagen than overall content of collagen. It is interesting to note that these differences were detectable in this study, even when contemporary steers were used.

The greater amounts of total, soluble, and insoluble values in the $\mathrm{CF}$ steers are probably due to dilution of collagen by muscle fiber growth as an animal ages. Many scientists have reported meat from younger cattle contains greater amounts of total and soluble collagen than older cattle (Wilson et al., 1954; Goll et al., 1963; Hill, 1966; Cross et al., 1973; Boccard et al., 1979; Cross et al., 1984). The collagen from the CF steers was much more soluble than from the YF steers (39.7 vs. 24.4\%, respectively). Solubility of collagen has been shown to be positively correlated to textural characteristics (Goll et al., 1963), although Miller et al. (1983) found contradictory results. Furthermore, the CF steers were on a high-concentrate diet for a longer period of time, which supports that rationale.

As expected, WBS values became lower $(P<0.001)$ with aging regardless of production system (Table 5). This confirms previous data showing shear force decreases up to $21 \mathrm{~d}$ of age (Field et al., 1971; Jennings et al., 1978).

Sensory traits were compared across grade and at aging times of 7 or $14 \mathrm{~d}$, whereas WBS was compared at aging times of 7, 14, or $21 \mathrm{~d}$ (Table 5). As expected, postmortem aging affected sensory traits of steaks. The WBS values for steaks improved $(P<0.001)$ with increased aging time from 7 to $14 \mathrm{~d}$ and from 14 to $21 \mathrm{~d}$ of age. These data also suggest that increased aging time has a detrimental effect on juiciness scores of steaks from $\mathrm{CF}$ and $\mathrm{YF}$ steers. In contrast, Miller et al. (1997) reported an increase in all palatability traits when aging time increased from 7 to $14 \mathrm{~d}$. Postmortem aging showed no significant effects on flavor or overall acceptability within steaks from our CF or YF cattle. Jennings et al. (1978) also showed no aging effects on flavor or overall desirability. Substantial differences between steaks from $\mathrm{CF}$ and YF cattle within each sensory panel session may have overshadowed any effects of aging on overall desirability in the current study. When like quality grades were grouped, USDA Choice steaks were rated greater $(P<0.01)$ for tenderness than Select steaks (Table 5). Aging improved the tenderness ratings for Select grade steaks $(P<0.001)$, but no effect due to aging was seen on the Choice grade steaks.

Miller et al. (2001) categorized tender, intermediate, and tough steaks as having less than $3.0 \mathrm{~kg}$, between 3.0 and $4.6 \mathrm{~kg}$, and greater than $4.6 \mathrm{~kg}$ of shear force, respectively. Using these limits, the risk probability of being tough was calculated for steaks from CF and YF steers (Table 6). Steaks from $\mathrm{CF}$ steers had a very low risk of being tough (1.24\%). These figures are similar to Klopfenstein et al. (1995) who showed 14-mo-old cattle had a very low $(0.01 \%)$ risk of being tough. Steaks from our YF steers had a much greater risk $(21.22 \%)$ of being tough than steaks from CF steers. However, the risk decreased substantially from $7 \mathrm{~d}$ of aging time $(37.02 \%)$ to $14(17.82 \%)$ and $21(7.15 \%) \mathrm{d}$ (data not shown). The current probabilities for steaks from YF steers showed a greater risk of being tough than results of Klopfenstein et al. (1995) who reported 19-mo-old cattle to have a $0.18 \%$ risk of being tough. However, the risk of steaks from YF steers being tough remains consistent with the 10,20, and $25 \%$ for upper two-thirds Choice, low Choice, and Select steaks, respectively, reported by George et al. (1999).

The probability of being categorized as desirable, slightly desirable, or undesirable was calculated using

Table 6. Probability, in percentages, for shear force values of LM steaks from calf- and yearling-finished steers ${ }^{1,2}$

\begin{tabular}{lcc}
\hline \hline Item & Calves & Yearlings \\
\hline Tender & 53.32 & 14.29 \\
Intermediate & 45.44 & 64.49 \\
Tough & 1.24 & 21.22 \\
\hline
\end{tabular}

${ }^{1}$ Shear force rate: $<3.0 \mathrm{~kg}=$ tender; 3.0 to $4.6 \mathrm{~kg}$ = intermediate; and $>4.6 \mathrm{~kg}=$ tough.

${ }^{2}$ Chi-squared for tenderness level by production group, $P<0.001$. 
Table 7. Probability, in percentages, for sensory ratings of LM steaks from calf- and yearling-finished steers ${ }^{1}$

\begin{tabular}{|c|c|c|c|c|c|c|c|}
\hline \multirow[b]{2}{*}{ Trait } & \multicolumn{3}{|c|}{ Calves } & \multicolumn{4}{|c|}{ Yearlings } \\
\hline & Desirable & $\begin{array}{l}\text { Slightly } \\
\text { desirable }\end{array}$ & Undesirable & Desirable & $\begin{array}{c}\text { Slightly } \\
\text { desirable }\end{array}$ & Undesirable & Chi-squared $^{2}$ \\
\hline Juiciness & 36.17 & 27.85 & 35.98 & 27.12 & 26.26 & 46.62 & $<0.001$ \\
\hline Tenderness & 51.50 & 24.98 & 23.52 & 25.83 & 23.35 & 50.82 & $<0.001$ \\
\hline Flavor & 36.11 & 26.98 & 36.91 & 27.18 & 25.70 & 47.12 & $<0.001$ \\
\hline Overall & 37.80 & 27.94 & 34.26 & 21.44 & 24.88 & 53.68 & $<0.001$ \\
\hline
\end{tabular}

${ }^{1}$ Acceptability rate: consumer sensory panel rating $>5.5=$ desirable; consumer sensory panel rating of 4.5 to 5.5 = slightly desirable; and consumer sensory panel rating $<4.5=$ undesirable.

${ }^{2}$ Chi-squared for trait by production group.

sensory ratings for juiciness, tenderness, flavor, and overall acceptability (Table 7). Limits were set for rating scores greater than 5.5 on an 8-point scale being desirable, between 4.5 and 5.5 as slightly desirable, and less than 4.5 being undesirable. Tenderness scores showed steaks from CF steers most likely ( $52 \%$ ) to be classified as desirable, although probabilities of $24 \%$ of being undesirable were also observed. Steaks from YF steers had $26 \%$ probability of being desirable in tenderness, but were more likely (51\%) to be undesirable in tenderness. Probabilities for juiciness, flavor, and overall acceptability of steaks from CF steers were similar for desirable or undesirable groups. Comparatively, steaks from YF steers were most probable to be undesirable for juiciness, flavor, and overall acceptability. Steaks from CF and YF cattle showed a much greater probability of being undesirable in juiciness, tenderness, flavor, and overall palatability than those shown previously shown for cattle slaughtered at 14, 19, and 21 mo of age (Klopfenstein et al., 1995).

In conclusion, growing genetically similar steers for a longer period of time on forage with a short finishing period resulted in heavier carcasses with lower quality grades and initially tougher, less palatable beef. When fed to a common fat thickness endpoint, steers finished as calves spent more days in the feedlot and produced a more desirable beef product. Yearling steers are more likely to produce tough beef, although increasing postmortem aging time greatly decreases that probability.

\section{LITERATURE CITED}

Aberle, E. D., E. S. Reeves, M. D. Judge, R. E. Hunsley, and T. W. Perry. 1981. Palatability and muscle characteristics of cattle with controlled weight gain: Time on a high energy diet. J. Anim. Sci. 52:757-763.

AMSA. 1995. Research Guidelines for Cookery, Sensory Evaluation, and Instrumental Tenderness Measurements for Fresh Meat. Am. Meat Sci. Assoc., Chicago, IL.

Anderson, R. V., R. J. Rasby, T. J. Klopfenstein, and R. T. Clark. 2005. An evaluation of production and economic efficiency of two beef systems from calving to slaughter. J. Anim. Sci. 83:694-704.

AOAC. 1990. Official Methods of Analysis. 15th ed. Assoc. Off. Anal. Chem. Arlington, VA.

Bergman, I., and R. Loxley. 1963. Two improved and simplified methods for the spectrophotometric determination of hydroxyproline. Anal. Chem. 35:1961-1965.
Boccard, R. L., R. T. Naude, D. E. Cronje, M. C. Smit, H. J. Venter, and E. J. Rossouw. 1979. The influence of age, sex, and breed of cattle on their muscle characteristics. Meat Sci. 3:261-280.

Brandt, L. A. 1998. Sensory evaluation hones good taste. Prep Foods 167:2.

Cross, H. R., Z. L. Carpentar, and G. C. Smith. 1973. Effects of intramuscular collagen and elastin on bovine muscle tenderness. J. Food Sci. 38:998-1003.

Cross, H. R., B. D. Schanbacher, and J. D. Crouse. 1984. Sex, age, and breed related changes in bovine testosterone and intramuscular collagen. Meat Sci. 10:187-195.

Dikeman, M. E., A. D. Dayton, M. C. Hunt, C. L. Kastner, J. B. Axe, and H. J. Ilg. 1985a. Conventional versus accelerated beef production with carcass electrical stimulation. J. Anim. Sci. 61:573-583.

Dikeman, M. E., K. N. Nagele, S. M. Myers, R. R. Schalles, D. H. Kropf, C. L. Kastner, and F. A. Russo. 1985b. Accelerated versus conventional beef production and processing. J. Anim. Sci. 61:137-150

Field, R. A., M. C. Riley, and Y. O. Chang. 1971. Free amino acid changes in different aged bovine muscles and their relationship to shear values. J. Food Sci. 36:611-612.

Foutz, C. P., H. G. Dolezal, T. L. Gardner, D. R. Gill, J. L. Hensley, and J. B. Morgan. 1997. Anabolic implant effects on steer performance, carcass traits, subprimal yields, and LM properties. J. Anim. Sci. 75:1256-1265.

George, M. H., J. D. Tatum, K. E. Belk, and G. C. Smith. 1999. An audit of retail beef loin steak tenderness conducted in eight U.S. cities. J. Anim. Sci. 77:1735-1741.

Gerken, C. L., J. D. Tatum, J. B. Morgan, and G. C. Smith. 1995. Use of genetically identical (clone) steers to determine the effects of estrogenic and androgenic implants on beef quality and palatability characteristics. J. Anim. Sci. 73:3317-3324.

Goll, D. E., R. W. Bray, and W. G. Huekstra. 1963. Age associated changes in muscle composition. The isolation and properties of collagenous residue from bovine muscle. J. Food Sci. 28:503-509.

Harris, J. J., D. K. Lunt, S. B. Smith, W. L. Mies, D. S. Hale, M. Koohmaraie, and J. W. Savell. 1997. Live animal performance, carcass traits, and meat palatability of calf- and yearling-fed cloned steers. J. Anim. Sci. 75:986-992.

Hill, F. 1966. The solubility of intramuscular collagen in meat animals of various ages. J. Food Sci. 31:161-166.

Huffman, R. D., S. E. Williams, D. D. Hargrove, D. D. Johnson, and T. T. Marshall. 1990. Effects of percentage Brahman and Angus breeding, age-season of feeding and slaughter end point on feedlot performance and carcass characteristics. J. Anim. Sci. 68:2243-2252.

Jennings, T. G., B. W. Berry, and A. L. Joseph. 1978. Influence of fat thickness, marbling and length of aging on beef palatability and shelf-life characteristics. J. Anim. Sci. 46:658-665.

Johnson, D. D., R. D. Huffman, S. E. Williams, and D. D. Hargrove. 1990. Effects of percentage Brahman and Angus breeding, ageseason of feeding and slaughter end point on meat palatability and muscle characteristics. J. Anim. Sci. 68:1980-1986. 
Klopfenstein, T., C. Calkins, C. Rossi, B. Vieselmeyer, and N. Meseck. 1995. Effect of age and time on feed on palatability characteristics and consumer acceptability. Pages 53-56 in Univ. Nebraska Beef Cattle Report. Agric. Res. Div., UNL Cooperative Extension, Lincoln, NE.

Lunt, D. K., and L. E. Orme. 1987. Feedlot performance and carcass evaluation of heifers fed finishing diets as weanling calves or as yearlings. Meat Sci. 20:159-164.

May, S. G., H. G. Dolezal, D. R. Gill, F. K. Ray, and D. S. Buchanan. 1992. Effects of days fed, carcass grade traits, and subcutaneous fat removal on postmortem muscle characteristics and beef palatability. J. Anim. Sci. 70:444-453.

Miller, M. F., M. A. Carr, C. B. Ramsey, K. L. Crockett, and L. C. Hoover. 2001. Consumer thresholds for establishing the value of beef tenderness. J. Anim. Sci. 79:3062-3068.

Miller, R. K., H. R. Cross, J. D. Crouse, and J. D. Tatum. 1987. The influence of diet and time on feed on carcass traits and quality. Meat Sci. 19:303-313.

Miller, M. F., C. R. Kerth, J. W. Wise, J. L. Landsdell, J. E. Stowell, and C. B. Ramsey. 1997. Slaughter plant location, USDA quality grade, external fat thickness, and aging time effects on sensory characteristics of beef loin strip steak. J. Anim. Sci. 75:662-667.

Miller, R. K., J. D. Tatum, H. R. Cross, R. A. Bowling, and R. P. Clayton. 1983. Effects of carcass maturity on collagen solubility and palatability of beef from grain-finished steers. J. Food Sci. 48:484-486, 525.

NAMP. 1997. The Meat Buyers Guide. North Am. Meat Processors, Reston, VA.

Reiling, B. A., and D. D. Johnson. 2003. Effects of implant regimes (trenbolone acetate-estradiol administered alone or in combination with zeranol) and vitamin $\mathrm{D}_{3}$ on fresh beef color and quality. J. Anim. Sci. 81:135-142.

Resurreccion, A. V. A. 1998. The consumer panel. Pages 71-92 in Consumer Sensory Testing for Product Development. Chapman and Hall, Gaithersburg, MD.

Savell, J. W., H. R. Cross, and G. C. Smith. 1986. Percentage ether extractable fat and moisture content of beef LM as related to USDA marbling score. J. Food Sci. 51:838, 840.

Schoonmaker, J. P., F. L. Fluharty, S. C. Loerch, T. B. Turner, S. J. Moeller, and D. M. Wulf. 2001. Effect of weaning status and implant regimen on growth, performance, and carcass characteristics of steers. J. Anim. Sci. 79:1074-1084.

Sindt, M., R. Stock, and T. Klopfenstein. 1991. Calf vs. yearling feeding. Pages 42-43 in Univ. Nebraska Beef Cattle Report. Agric. Res. Div., UNL Cooperative Extension, Lincoln, NE.

Wilson, G. D., R. W. Bray, and P. H. Phillips. 1954. The effect of age and grade on collagen and elastin content of beef and veal. J. Anim. Sci. 13:826-831. 